\title{
Suicide Coverage in the Digital Press Media: Adherence to World Health Organization Guidelines and Effectiveness of Different Interventions Aimed at Media Professionals
}

Francisco J. Acosta , Carlos J. Rodríguez, María R. Cejas , Yolanda RamalloFariña \& Helena Fernandez-Garcimartin

To cite this article: Francisco J. Acosta, Carlos J. Rodríguez, María R. Cejas, Yolanda Ramallo-Fariña \& Helena Fernandez-Garcimartin (2020) Suicide Coverage in the Digital Press Media: Adherence to World Health Organization Guidelines and Effectiveness of Different Interventions Aimed at Media Professionals, Health Communication, 35:13, 1623-1632, DOI: 10.1080/10410236.2019.1654176

To link to this article: https://doi.org/10.1080/10410236.2019.1654176

Published online: 30 Aug 2019.

Џ Article views: 176

View Crossmark data
Submit your article to this journal 지

Q View related articles $₫$

Citing articles: 1 View citing articles $\llbracket$ 


\title{
Suicide Coverage in the Digital Press Media: Adherence to World Health Organization Guidelines and Effectiveness of Different Interventions Aimed at Media Professionals
}

\author{
Francisco J. Acosta $\mathbb{1}^{\mathrm{a}, \mathrm{b}, \mathrm{c}}$, Carlos J. Rodríguez ${ }^{\mathrm{d}, \mathrm{e} *}$, María R. Cejas ${ }^{\mathrm{f}, \mathrm{g}}$, Yolanda Ramallo-Fariña ${ }^{\mathrm{b}, \mathrm{h}}$, \\ and Helena Fernandez-Garcimartin ${ }^{\mathrm{i}}$
}

a Service of Mental Health, General Management of Healthcare Programs, The Canary Islands Health Service; ${ }^{b}$ Research Network on Health Services for Chronic Conditions (REDISSEC), Carlos III Health Institute; 'Department of Psychiatry, Insular University Hospital of Gran Canaria; dDepartment of

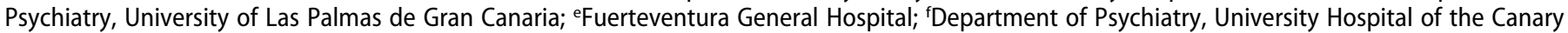

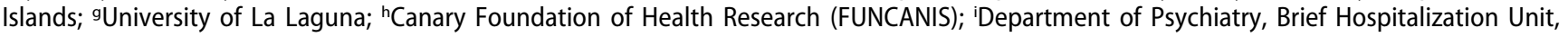
University Hospital Infanta Sofía

\begin{abstract}
This study evaluated the characteristics of suicide news articles in the digital press, their adherence to World Health Organization (WHO) recommendations, and the effectiveness of interventions. We assessed adherence, avoidability, frequency and typology of suicide news over a six-month period in the four main digital media outlets of the Canary Islands (Spain). A brief training and information package intervention to the Canary Islands media outlets was carried out. We compared the quality of media reporting at both the pre-intervention and post-intervention timepoints, and compared the quality of reporting at the post-intervention timepoint in Victoria (Australia), where media interventions have been well-resourced and running for several years. We evaluated 339 suicide news articles: 38 from the pre-intervention period, 64 from the post-intervention period, and 237 from Victoria. News articles showed a very low degree of adherence to WHO recommendations, especially to those recommendations thought to have a protective effect. Post-intervention news articles showed better adherence than pre-intervention ones, but lower than those of Victoria, where constant interventions have been developed for years. We conclude that adherence to WHO recommendations is low. Simple interventions aimed at media professionals can improve adherence. However, constant and complex interventions seem to be more effective.
\end{abstract}

\section{Introduction}

Inappropriate suicide media reporting may have a contagion effect or "Werther effect" (Sisask \& Värnik, 2012; Stack, 2003). Presenting simplistic explanations for suicide, providing sensational coverage, describing technical details about the method, or glorifying suicide or people who commit suicide are some of the characteristics that can promote suicide contagion. On the other hand, the "Papageno effect" refers to a positive effect (e.g., reduction in suicide, decrease in suicide risk, improvement in life satisfaction, etc.) induced by stories on coping with adverse circumstances (Niederkrotenthaler et al., 2010). Stories about seeking help in crisis and suicidal ideation (Phillips, Lesyna, \& Paight, 1992), positive coping in adverse circumstances or suicidal ideation not accompanied by suicidal behavior have a protective effect (Niederkrotenthaler et al., 2010).

Since suicide media reporting may influence suicidal behavior in the general population, raising awareness among media professionals is a priority concern. In this context, the WHO has developed recommendations for the reporting of suicides (WHO, 2000, 2008, 2017). Unfortunately, adherence to such recommendations has generally been poor. Thus, in US, despite the publication of consensus recommendations, newspaper coverage of suicide cases in the following two years did not consistently adhere to them. Although there was some improvement, news coverage did not change for most key recommendations (Tatum, Canetto, \& Slater, 2010). In China, the most influential newspaper and Internet media sources from 2003 to 2015 showed poor and inconsistent adherence to WHO suicide media reporting recommendations (Chu, Zhang, Cheng, Schwebel, \& Hu, 2018). In Tamil Nadu, India, a high frequency of suicide articles and harmful reporting characteristics was found (Armstrong et al., 2018). In Hong Kong, Taiwan and Guangzhou non-compliant suicide articles were prevalent (Fu, Chan, \& Yip, 2011). These findings suggest the need for sustained dialog and collaboration with the media about the responsible reporting of suicide, as has been previously recommended (Tatum et al., 2010).

The development of interventions aimed at media professionals has been uneven across countries. In Europe, whereas countries such as Austria and Germany have carried out

CONTACT Francisco J. Acosta fjacostaartiles@hotmail.com Acosta Consejería de Sanidad, 3a planta, Dirección General de Programas Asistenciales, C/Pérez del Toro (Plaza Dr. Juan Bosch Millares, 1), E-35.004 Las Palmas de Gran Canaria, Gran Canaria, Spain.

*Present address: Department of Psychiatry, La Fe University and Polytechnic Hospital, Valencia, Spain.

(c) 2019 Taylor \& Francis Group, LLC 
several important interventions, in other countries such as Spain, this has not been the case. Spain had a suicide rate of 7.91 per 100,000 population in 2017, whereas that of the Canary Islands was greater, 9.49 (NSI, 2019). Despite the fact that the Ministry of Health has recommended adherence to WHO guidelines on responsible reporting on suicide, dissemination and training interventions based on them (MSPSI, 2012), there have been no planned interventions either in Spain or in the Canary Islands. Besides, newspaper coverage of suicide cases in Spain has shown poor adherence to WHO recommendations (Herrera Ramírez, Ures Villar, \& Martínez Jambrina, 2015). In contrast, in Australia the Australian Government's Mindframe National Media Initiative (Mindframe) has been developed since 2002, which comprises the creation and dissemination of national guidelines, training of students and journalists, development of web pages with guidelines and collaboration with journalists, among other actions (Australian Government under the National Suicide Prevention Program \& Everymind, 2018). There are still few studies that have investigated the possible modification of reporting on suicidal behavior after interventions aimed at media professionals, but there is evidence that it is feasible and that they can be effective (Sisask \& Värnik, 2012). Few studies have analyzed the quality of information in suicide news before and after the publication of recommendations and dissemination campaigns (Etzersdorfer \& Sonneck, 1998; Fu \& Yip, 2008; Pirkis et al., 2009) and even fewer that include training of the media professionals (Michel, Wyss, Frey, \& Valach, 2000; Pirkis et al., 2009). These interventions have led to a better quality of suicide news articles (Michel et al., 2000; Pirkis et al., 2009). Surprisingly, evidence of the effectiveness of constant and complex interventions is still lacking.

We initially hypothesized that an intervention composed of training, dissemination of WHO guidelines and a reminder would improve the quality of suicide news articles. We hypothesized as well that the quality of suicide news articles after this intervention in the Canary Islands would be inferior to that of an area with constant and complex intervention.

In this context, we carried out this study with the following objectives:

(1) To evaluate the characteristics of suicide news articles in the digital press of the Canary Islands, in terms of frequency, typology, avoidability, and adherence to WHO recommendations.

(2) To assess the effectiveness of an intervention in the Canary Islands.

(3) To compare the effectiveness of the intervention in the Canary Islands with that of a constant and complex intervention (Victoria).

\section{Methods}

\section{Sample}

The inclusion criterion was suicide or suicidal behavior news articles, which were defined as those whose main subject was suicide or suicidal behavior. Exclusion criteria were news articles whose main subject was related to i) figurative use of suicide or suicidal; ii) suicide in the context of terrorist attacks; iii) fictitious suicide.

Suicide or suicidal behavior news articles in the main general interest digital newspapers were analyzed. Selection of the digital newspapers was based on the readership. The readership was obtained through Alexa, the only measuring tool that evaluates all existing web pages (Alexa Internet, Inc., 2017) as of May 1, 2017.

The most visited newspapers of the Canary Islands were $L a$ Provincia, Canarias 7, El Día and La Opinión; and of Victoria, The Age, Herald Sun, The Courier and Geelong Advertiser. The evaluation period was six months, from November 1, 2016 to April 30, 2017 for the Canary Islands pre-intervention and Victoria; and from December 15, 2017 to June 13, 2018, for the Canary Islands post-intervention. According to national statistics offices, in 2017 the Canary Islands and Victoria had populations of 2,108,121 (National Statistics Institute [NSI], 2018a) and 6,292,584 inhabitants (Australian Bureau of Statistics [ABS], 2018) respectively.

\section{Procedure}

The searching was performed using Google, using the word "suicid *", time filters and filters to restrict the searches to the selected newspaper web pages. The evaluation was performed independently by two psychiatrists (C.R. and H.F.), who had previously completed a training period assessing all variables and items in a different sample, until consensus was reached. Sample selection and evaluation procedures are shown in Figure 1.

Although frequency and typology were assessed in all news articles for descriptive purposes, adherence and avoidability were only assessed in news articles about people. Contagion effect is greater in news about people, especially in cases of a famous person worshiped by the reader (Blood \& Pirkis, 2001; Niederkrotenthaler et al., 2009; Tatum et al., 2010) or someone with similar circumstances (Blood \& Pirkis, 2001; Cheng, Hawton, Lee, \& Chen, 2007). Besides, most of the WHO recommendations refer to this type of news (Acosta Artiles, Rodriguez Rodríguez-Caro, \& Cejas Méndez, 2017). The study was approved by the Ethics Committee of Hospital Universitario de Gran Canaria Dr. Negrín.

\section{Variables}

- Adherence: Adherence to WHO recommendations (henceforth "adherence") was evaluated with a scale developed through a systematic procedure which combined scientific and linguistic criteria to obtain a single list of recommendations from the three published WHO documents (WHO, 2000, 2008, 2017). Both the detailed operative procedure and the list of recommendations have been published elsewhere (Acosta Artiles et al., 2017). The recommendations are structured in three sections: "What To Avoid" (WTA), to avoid a contagion effect; "What To Do" (WTD), to have a protective effect; and Other Recommendations (OR). The scoring of the ad hoc scale is based on the scores of WTA and WTD recommendations, but not of OR, given their 


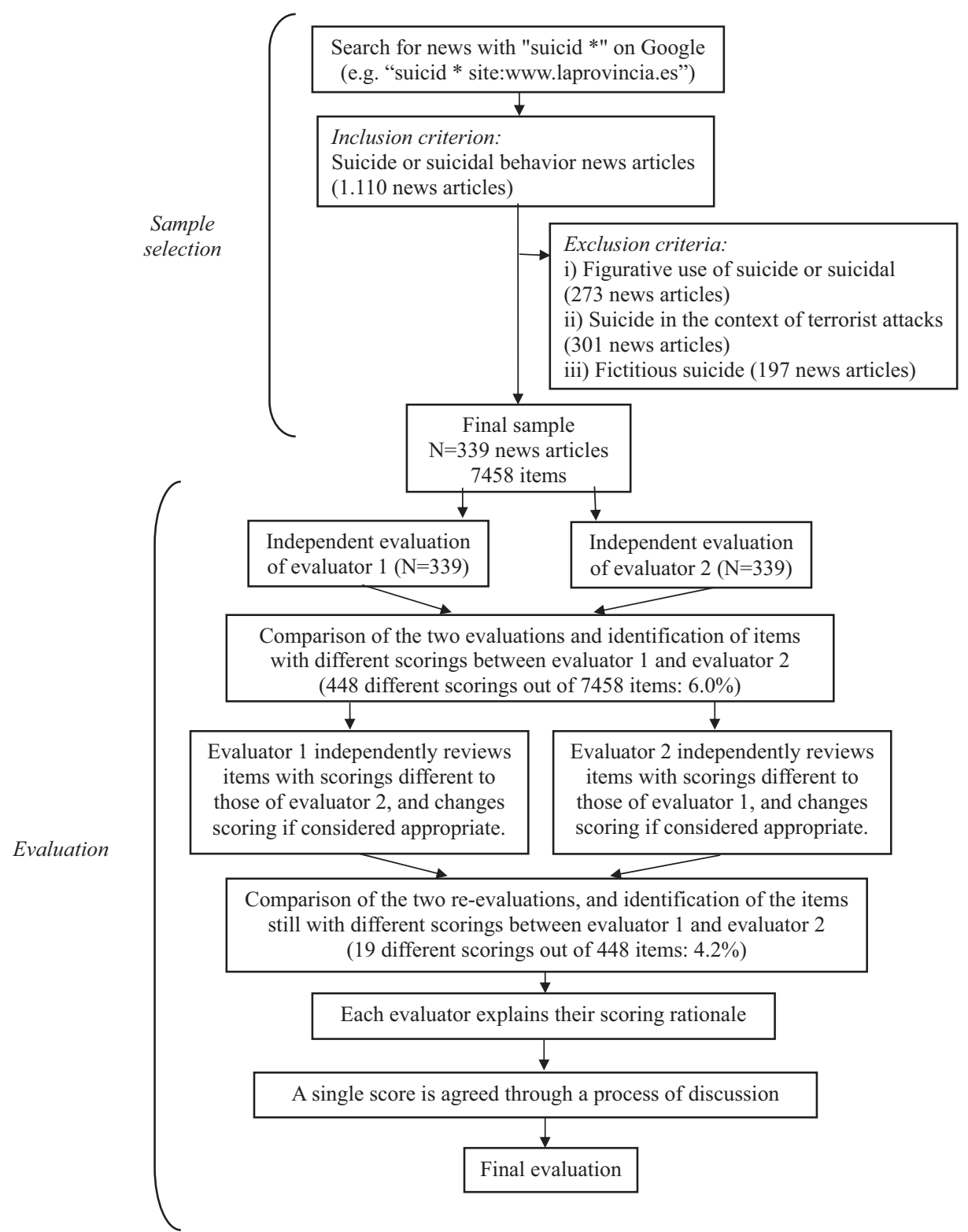

Figure 1. Flow chart on sample selection and evaluation procedures.

different nature, generally not measurable in the news contents.

We evaluated adherence from a continuous perspective, based on the total scoring. Since each recommendation scored +1 (adherence) or -1 (non-adherence), the scoring range was +15 to -15 for WTA, +7 to -7 for WTD, and +22 to -22 for the total scale. Additionally, adherence to each specific recommendation was assessed.

Avoidability: We defined as avoidable those news articles communicating about any case of suicide previously reported in the same newspaper, and those potentially negative (nonadherence) which did not fit within the following categories: mass suicide, suicide after murder, suicide with public disorder, suicide of a famous person. We defined this concept not from an idealistic approach (every article on suicide is avoidable) but from a realistic one. As it has been pointed out, it is possible to change media reports, but this is not possible by forcing journalists, and of course, it is not possible to forbid reports about suicide totally (Etzersdorfer \& Sonneck, 1998).

Frequency: number and mean daily number of selected suicide news articles during the evaluation period. Quantity of media reporting is an important variable, since greater numbers of media items have been associated with a stronger contagion effect (Pirkis, Blood, Beautrais, Burgess, \& Skehan, 2006).

Typology: As previously pointed out, typology of suicide news articles may be a relevant variable. For example, studies of celebrity suicides were five times more likely to find an imitation effect (Stack, 2005). Suicide news articles were assigned to 
Table 1. Comparison of suicide news in the Canary Islands digital press before and after the intervention.

\begin{tabular}{|c|c|c|c|c|c|c|c|}
\hline & & $\begin{array}{l}\text { Pre- } \\
\text { intervention }\end{array}$ & $\begin{array}{l}\text { Post- } \\
\text { intervention }\end{array}$ & Total & $\begin{array}{l}\text { Statistical } \\
\text { Test }\end{array}$ & $P$-value & $\begin{array}{l}\text { Power } \\
\text { (\%) }\end{array}$ \\
\hline \multicolumn{2}{|l|}{ Frequency, n (\%) } & $38(37.2)$ & $64(62.8)$ & 102 & - & - & - \\
\hline \multicolumn{2}{|c|}{ Frequency, average number of suicide articles per day, mean (standard deviation) } & $0.21(0.56)$ & $0.35(0.98)$ & - & $\mathrm{t}=-0.84$ & 0.406 & - \\
\hline \multirow{4}{*}{$\begin{array}{l}\text { Typology by subject } \\
\text { (three most frequent } \\
\text { types) }\end{array}$} & Suicide after murder, $\mathrm{n}(\%)$ & $20(62.5)$ & $30(55.6)$ & 50 & $X^{2}=3.82$ & 0.148 & \\
\hline & $\begin{array}{l}\text { Suicide of a non-famous person without public disorder, } \\
\mathrm{n}(\%)\end{array}$ & $8(25)$ & $8(14.8)$ & 16 & & & - \\
\hline & Suicide of a famous person, $\mathrm{n}(\%)$ & $4(12.5)$ & $16(29.6)$ & 20 & & & \\
\hline & Total, n (\%) & $32(100)$ & $54(100)$ & 86 & & & \\
\hline \multirow{11}{*}{$\begin{array}{l}\text { Typology by subject } \\
\text { (others) }\end{array}$} & Suicide of a non-famous person with public disorder & 0 & 2 & & - & - & \\
\hline & Mass suicide & 0 & 0 & & & & \\
\hline & Assisted suicide & 0 & 3 & & & & \\
\hline & Statistics about suicide & 1 & 1 & & & & \\
\hline & Policies and programs on suicide & 1 & 2 & & & & \\
\hline & Research on suicide & 0 & 0 & & & & - \\
\hline & Causes of suicide & 0 & 0 & & & & \\
\hline & First-person experiences & 0 & 0 & & & & \\
\hline & Opinion article & 0 & 0 & & & & \\
\hline & Legal issues in suicide & 2 & 1 & & & & \\
\hline & Others & 2 & 1 & & & & \\
\hline \multirow{4}{*}{$\begin{array}{l}\text { Typology by suicidal } \\
\text { behavior }\end{array}$} & Suicide death, n (\%) & $36(94.7)$ & $61(95.3)$ & 97 & - & $0.999^{¥}$ & \\
\hline & Suicide attempt, n (\%) & $2(5.3)$ & $3(4.7)$ & 5 & & & - \\
\hline & Suicidal ideation, $\mathrm{n}(\%)$ & $0(0.0)$ & $0(0.0)$ & 0 & & & \\
\hline & Total, n (\%) & $38(100)$ & $64(100)$ & 102 & & & \\
\hline \multirow[t]{3}{*}{ Avoidability } & Unavoidable, n (\%) & $25(78.1)$ & $35(59.3)$ & 60 & $x^{2}=3.27$ & 0.071 & \\
\hline & Avoidable, n (\%) & $7(21.9)$ & $24(40.7)$ & 31 & & & - \\
\hline & Total, n (\%) & $32(100)$ & $59(100)$ & 91 & & & \\
\hline \multicolumn{2}{|c|}{ Level of adherence, mean (standard deviation)* } & $3.75(3.86)$ & $5.69(3.52)$ & - & $\mathrm{t}=-2.43$ & 0.017 & 70.9 \\
\hline \multicolumn{2}{|c|}{ WTA level of adherence, mean (standard deviation)* } & $7.75(3.93)$ & $9.54(2.97)$ & - & $\mathrm{t}=-2.45$ & 0.016 & 66.6 \\
\hline \multicolumn{2}{|c|}{ WTD level of adherence, mean (standard deviation)* } & $-4.0(2.16)$ & $-3.85(1.54)$ & - & $t=-0.39$ & 0.697 & 6.6 \\
\hline
\end{tabular}

*: measures calculated only for suicide news articles about people.

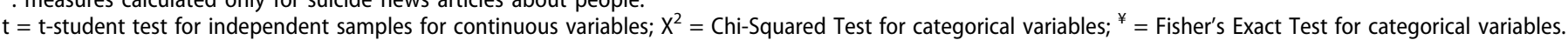

categories according to suicidal behavior and main subject. These categories are shown in Table 1 .

\section{Intervention. Training course and dissemination of recommendations}

The intervention developed in the Canary Islands was organized and conducted by the Mental Health Service, General Management of Healthcare Programs, in collaboration with the Ministry of Health Press Office, within the context of scheduled preventive actions against suicidal behavior. Its objective was to provide basic knowledge about suicidal risk, suicidal behavior, contagion and protective effects of suicide news depending on their characteristics, and WHO recommendations.

It was taught by a psychiatrist in both provinces of the Canary Islands in May 2017, with 25 and 21 participants, respectively. It was addressed to all media professionals (print and digital newspapers, and audiovisual media). Different recommendations from previous research were followed, such as a face-to-face and flexible approach, information exchange and research evidence on contagion effect (Bohanna \& Wang, 2012; Skehan, Greenhalgh, Hazell, \& Pirkis, 2006). The course lasted three hours, it was both theoretical and practical, interactive, and included analyses of real news articles as a way of illustrating good and bad practice.

After the course, a summary document was sent to both the participants and the directors of each Canary Islands media outlet, to be disseminated to all professionals within their media outlet. This document included a brief introduction and the list of WHO recommendations: WTA, WTD, and OR. Lastly, the files were sent to the media directors again six months later.
This document included the definitive version of the recommendations (Acosta Artiles et al., 2017). On both occasions, the dissemination encompassed 433 people, including print and digital newspapers, radio, TV, Communication Agencies, and 44 professionals from the Canary Islands Ministry of Health.

\section{Statistical analysis}

In this observational, descriptive and analytical study, quantitative variables were reported using arithmetic mean, standard deviation and 95\% confidence interval (CI). Qualitative variables were represented by absolute and relative frequency of each category. Chi-Squared test and Fisher's exact test were used to test differences for qualitative variables and independent t-tests were used to test differences for quantitative variables. Chi-square tests were used when the cell sizes were large, whereas Fisher's Exact tests were used when the cell sizes were small (more than $20 \%$ of cells had expected frequencies $<5$ ). $P$-values were two-tailed; statistical significance was considered attained when $p<.05$. Tendency to significance was considered for $p$-values between 0.05 and 0.1. Statistical analysis was performed with the SPSS for Windows version 22 software package (SPSS Inc., Chicago, IL, USA).

\section{Results}

According to inclusion and exclusion criteria, we selected and evaluated a total of 339 suicide news articles: 38 belonging to the Canary Islands pre-intervention subsample, 64 to the Canary Islands post-intervention subsample and 237 to the Victoria subsample. 


\section{Canary Islands, pre-intervention}

Out of a total sample of 38 news articles, the most frequent typology by subject was "suicide after murder" $(\mathrm{n}=20$; $52.6 \%$ ). The most frequent typology by suicidal behavior was "suicide death" ( $\mathrm{n}=36$; 94.7\%). Characteristics of news articles are shown in Table 1.

Most of the news articles about people $(\mathrm{n}=32)$ were "unavoidable" ( $\mathrm{n}=25 ; 78.1 \%)$. Total adherence level showed a mean of 3.75 (95\% CI, 2.36-5.14), WTA adherence level showed a mean of 7.75 (95\% CI, 6.33-9.17), and that of WTD was -4.0 ( $95 \% \mathrm{CI},-4.78--3.22)$.

\section{Canary Islands, pre vs. post-intervention}

In the post-intervention period, as compared to the preintervention period, global adherence scoring was greater (5.69 vs. $3.75 ; P=.017$ ), as well as that of the WTA subscale (9.54 vs. $7.75 ; P=.016)$ but not that of the WTD subscale $(-3.85$ vs. $-4.0 ; P=.697)$. Besides, there was greater adherence to four specific recommendations: WTA1, WTA10, WTA11, and WTD5. These differences and the rest of variables are shown in Tables 1 and 2. Finally, as opposed to the preintervention period, no news article showed negative scoring of adherence, all showed positive scores in the WTA subscale, and there were some news articles in which full adherence to WTA subscale was attained.

Regarding frequency, we did not find statistically significant differences in mean daily number of suicide news articles between both periods. Avoidability was greater in the postintervention period $(40.7 \%$ vs. $21.9 \%, P=.071)$. Typologies by subject and suicidal behavior showed no differences between both periods.

\section{Victoria vs. Canary Islands post-intervention}

Victoria and the Canary Islands post-intervention showed differences in mean daily number of suicide news articles (1.31 vs. $0.35, P<.001)$. In contrast, we found no differences in avoidability $(43.5 \%$ vs. $40.7 \%, P=.753)$. Nevertheless, adherence level was greater in Victoria, both in the total scale (11.8 vs. $5.69 ; P<.001)$, WTA subscale (11.38 vs. 9.54; $P<.001)$, and WTD subscale $(0.42$ vs. $-3.85 ; P<.001)$. We found differences in typology by subject $(P=.006)$ and by suicidal behavior $(P=.066)$. A full comparison between both regions is shown in Table 3.

\section{Discussion}

To the best of our knowledge, this is the first study to compare adherence to WHO recommendations between two regions in which different types of interventions aimed at media professionals have been implemented.

\section{Canary Islands, pre-intervention}

Our results on adherence imply a low global adherence, a modest adherence to the recommendations to avoid the contagion effect and a marked deficiency in the inclusion of protective aspects.
Since there has been no official dissemination of the WHO guidelines in Spain, many journalists may be unaware of their existence. Finally, the assessment of the degree of adherence to the specific recommendations can reveal the most pressing training needs. Consistent with our findings, several studies have found a very low level of adherence to WTD recommendations (Chu et al., 2018; Frey, Michel, \& Valach, 1997; Gould, Midle, Insel, \& Kleinman, 2007; Jamieson, Jamieson, \& Romer, 2003; Niederkrotenthaler et al., 2010; Tatum et al., 2010).

Finally, most news articles were classified as "non-avoidable" (78.1\%). Since there are no other studies that have evaluated avoidability, we cannot compare this finding. Avoidability is a relevant feature, since the contagion effect depends not only on the quality of the news but also on the quantity (Niederkrotenthaler \& Sonneck, 2007; Pirkis et al., 2006).

\section{Canary Islands, pre- and post-intervention}

Consistently with our hypothesis, the news articles in the postintervention period scored better on several variables compared to the pre-intervention period. Thus, adherence was greater on a global perspective, on the WTA subscale, and in several specific recommendations. The lack of improvement in the WTD subscale is consistent with the very low level of adherence to these recommendations found in many other studies, as previously remarked. Of note was the fact that there was no article in any period reporting an instance of suicidal ideation. These articles are recommended by $\mathrm{WHO}$ and the findings suggest a protective effect (Niederkrotenthaler et al., 2010; Pirkis et al., 2006). Other authors have found a very low percentage of news articles on suicidal ideation, such as $2.0 \%$ (Armstrong et al., 2018), 5.2\% (Niederkrotenthaler et al., 2010) and 8.9\% (Pirkis et al., 2009). We found an increase in avoidable news articles in the postintervention period, from $21.9 \%$ to $40.7 \%$. Interventions may improve self-confidence on how to write this type of news and foment information on this subject. In line with this argument, the percentage of avoidable news in Victoria was similar, 43.5\%. The partial effectiveness found in our study may be influenced by several factors, such as shortage of time to write the news articles, a possible sensationalist tendency, the limited number of participants to the training course, and the fact that although dissemination of recommendations was made to all participants and directors of media, it cannot be assured that they were actually distributed among all media professionals.

Other studies have found partial improvement in adherence to recommendations after different interventions. In Hong Kong, following an intervention consisting of the development and dissemination of a leaflet with the WHO recommendations, an increase in adherence to some of them was found (Fu \& Yip, 2008). In Switzerland, after a lecture at a national press conference on inadequate news on suicide and guidelines to write them, an improvement in adherence was found (Michel et al., 2000). In Austria, following the dissemination of national guidelines, there was a reduction in headlines containing the word "suicide" or derivatives (Niederkrotenthaler \& Sonneck, 2007). Using a different approach, a workshop intervention on responsible reporting on suicide (RRS) among Swiss media professionals increased perceived knowledge sufficiency, decreased insecurities, raised awareness that RRS can save lives, 
Table 2. Comparison of suicide news in the Canary Islands digital press before and after the intervention. Adherence to specific WHO recommendations.

\begin{tabular}{|c|c|c|c|c|c|c|}
\hline & $\begin{array}{l}\text { Pre-intervention } \\
\quad(\mathrm{n}=32)\end{array}$ & $\begin{array}{l}\text { Post-intervention } \\
\quad(\mathrm{n}=59)\end{array}$ & Total & Statistical Test & $P$-value & $\begin{array}{l}\text { Power } \\
(\%)\end{array}$ \\
\hline WTA1 & $27(84.4)$ & $59(100)$ & 86 & - & $0.004^{*}$ & 84.5 \\
\hline $\begin{array}{l}\text { Sensationalism } \\
\text { WTA2 } \\
\text { Headlines }\end{array}$ & $5(15.6)$ & $14(23.7)$ & 19 & $X^{2}=0.83$ & 0.364 & 15.3 \\
\hline $\begin{array}{l}\text { WTA3 } \\
\text { Pictures or video }\end{array}$ & $32(100)$ & $58(98.3)$ & 90 & - & $0.999^{*}$ & 6.7 \\
\hline $\begin{array}{l}\text { WTA4 } \\
\text { Suicide notes }\end{array}$ & $32(100)$ & 57 (96.6) & 89 & - & $0.539^{¥}$ & 14.4 \\
\hline $\begin{array}{l}\text { WTA5 } \\
\text { Visibility of news article }\end{array}$ & $22(68.8)$ & $33(55.9)$ & 55 & $X^{2}=1.43$ & 0.232 & 24.6 \\
\hline $\begin{array}{l}\text { WTA6 } \\
\text { Detailed account of method }\end{array}$ & $6(18.8)$ & $20(33.9)$ & 26 & $X^{2}=2.33$ & 0.127 & 36.6 \\
\hline $\begin{array}{l}\text { WTA7 } \\
\text { Detailed account of location }\end{array}$ & $24(75.0)$ & $40(67.8)$ & 64 & $X^{2}=0.52$ & 0.473 & 11.5 \\
\hline $\begin{array}{l}\text { WTA8 } \\
\text { Glorification }\end{array}$ & $32(100)$ & $59(100)$ & 91 & - & - & - \\
\hline $\begin{array}{l}\text { WTA9 } \\
\text { Normalization }\end{array}$ & $32(100)$ & $59(100)$ & 91 & - & - & - \\
\hline $\begin{array}{l}\text { WTA10 } \\
\text { Suicide as a solution }\end{array}$ & $23(71.9)$ & $54(91.5)$ & 77 & - & $0.03^{*}$ & 73.0 \\
\hline $\begin{array}{l}\text { WTA11 } \\
\text { Simplistic reasons }\end{array}$ & $18(56.3)$ & 57 (96.6) & 75 & $X^{2}=23.32$ & $<0.001$ & 99.9 \\
\hline $\begin{array}{l}\text { WTA12 } \\
\text { Religinus or cultural stereotynes }\end{array}$ & $32(100)$ & $58(98.3)$ & 90 & - & $0.999^{*}$ & 6.7 \\
\hline $\begin{array}{l}\text { Religious or cultural stereotypes } \\
\text { WTA13 } \\
\text { Understandable response }\end{array}$ & $28(87.5)$ & $54(91.5)$ & 82 & - & $0.715^{¥}$ & 11.1 \\
\hline $\begin{array}{l}\text { WTA14 } \\
\text { Blame }\end{array}$ & $27(84.4)$ & $56(94.9)$ & 83 & - & $0.124^{*}$ & 43.9 \\
\hline $\begin{array}{l}\text { WTA15 } \\
\text { Repetition }\end{array}$ & $24(75.0)$ & $46(78)$ & 70 & $X^{2}=0.10$ & 0.748 & 6.7 \\
\hline $\begin{array}{l}\text { WTD1 } \\
\text { Completed suicide }\end{array}$ & $28(87.5)$ & $54(91.5)$ & 82 & - & $0.715^{*}$ & 11.1 \\
\hline $\begin{array}{l}\text { WTD2 } \\
\text { Alternatives to suicide }\end{array}$ & $3(9.4)$ & $5(8.5)$ & 8 & - & $0.999^{*}$ & 5.5 \\
\hline $\begin{array}{l}\text { WTD3 } \\
\text { Support resources }\end{array}$ & $1(3.1)$ & $0(0.0)$ & 1 & - & $0.352^{*}$ & 34.1 \\
\hline $\begin{array}{l}\text { WTD4 } \\
\text { Risk factors and warning signs }\end{array}$ & $7(21.9)$ & $13(22)$ & 20 & $X^{2}=0$ & 0.986 & 4.9 \\
\hline $\begin{array}{l}\text { WTD5 } \\
\text { Depression often associated }\end{array}$ & $1(3.1)$ & $11(18.6)$ & 12 & - & $0.05^{*}$ & 64.4 \\
\hline $\begin{array}{l}\text { WTD6 } \\
\text { Sympathy to the survivors }\end{array}$ & $7(21.9)$ & $10(16.9)$ & 17 & $X^{2}=0.33$ & 0.565 & 10.2 \\
\hline $\begin{array}{l}\text { WTD7 } \\
\text { Educate the public }\end{array}$ & $1(3.1)$ & $0(0.0)$ & 1 & - & $0.352^{*}$ & 34.1 \\
\hline
\end{tabular}

Each recommendation has been labeled for the sake of clarity. For the detailed contents of each recommendation, see Appendix.

Data are $\mathrm{n}(\%)$ in pre-intervention and post-intervention columns. $\mathrm{t}=\mathrm{t}$-student test for independent samples for continuous variables; $\mathrm{X}^{2}=\mathrm{Chi}$-Squared Test for categorical variables; ${ }^{¥}=$ Fisher's Exact Test for categorical variables.

and reduced the misperception that there are no clear recommendations about RRS (Scherr, Markiewitz, \& Arendt, 2019).

The partial effectiveness found in this study may have implications in suicide prevention. Our intervention was composed of a training course, dissemination of WHO recommendations, and a reminder after six months. This intervention is easy to carry out and it is probably costeffective, and attains beneficial effects on RSS.

\section{Victoria vs. Canary Islands, post-intervention}

The higher mean frequency of suicide articles found in Victoria cannot be explained either by a greater suicide rate or by the greater population. In fact, suicide rate per 100,000 population in 2017 was similar in Victoria and the Canary Islands: 9.6 vs. 9.49, respectively (ABS, 2019; National Statistics Institute (NSI) [Instituto Nacional de Estadística], 2019). Other authors have found a better quality of information on suicide in regions in which different interventions are implemented, but also a higher frequency of suicide articles (Michel et al., 2000; Ramadas \& Kuttichira, 2011).

Global adherence level and those of the WTA and WTD subscales were greater in Victoria. In addition, Victoria showed more news on suicidal ideation, which are associated with a protective effect (Niederkrotenthaler et al., 2010). Therefore, in agreement with our hypothesis, the adherence level was greater in the region in which planned and periodic training activities at multiple levels are carried out.

\section{Limitations and strengths}

Since the analysis of news articles was restricted to digital press, our findings cannot be generalized to other media. This restriction was justified by feasibility and the fact that analyzed media have also printed versions, whose contents are generally identical. Besides, according to a recent national survey, up to $77.5 \%$ of the Spanish population declares to read digital newspapers (NSI, 2018b). On the other hand, 
Table 3. Suicide news in digital press. Comparison between Victoria and the Canary Islands, post-intervention.

\begin{tabular}{|c|c|c|c|c|c|c|c|}
\hline & & Victoria & $\begin{array}{l}\text { Canary } \\
\text { Islands }\end{array}$ & Total & $\begin{array}{l}\text { Statistical } \\
\text { Test }\end{array}$ & $P$-value & $\begin{array}{c}\text { Power } \\
\text { (\%) }\end{array}$ \\
\hline \multirow{2}{*}{\multicolumn{2}{|c|}{$\begin{array}{l}\text { Frequency, } \mathrm{n}(\%) \\
\text { Frequency, daily average number of suicide articles, mean (standard deviation) }\end{array}$}} & $237(78.7)$ & $64(21.3)$ & 301 & - & - & - \\
\hline & & $1.31(1.22)$ & $0.35(0.98)$ & - & $\mathrm{t}=5.77$ & $<0.001$ & - \\
\hline \multirow{4}{*}{$\begin{array}{l}\text { Typology by subject } \\
\text { (three most frequent } t\end{array}$} & Suicide after murder, n (\%) & $38(31.4)$ & $30(55.6)$ & 68 & $x^{2}=10.31$ & 0.006 & - \\
\hline & $\begin{array}{l}\text { Suicide of a non-famous person without public disorder, } \\
n(\%)\end{array}$ & $39(32.2)$ & $8(14.8)$ & 47 & & & \\
\hline & Suicide of a famous person, $\mathrm{n}(\%)$ & $44(36.4)$ & $16(29.6)$ & 60 & & & \\
\hline & Total, n (\%) & $121(100)$ & $54(100)$ & 175 & & & \\
\hline \multirow{4}{*}{$\begin{array}{l}\text { Typology by suicidal } \\
\text { behavior }\end{array}$} & Suicide death, n (\%) & $202(85.2)$ & $61(95.3)$ & 263 & - & $0.066^{¥}$ & - \\
\hline & Suicide attempt, n (\%) & $22(9.3)$ & $3(4.7)$ & 25 & & & \\
\hline & Suicidal ideation, $\mathrm{n}(\%)$ & $13(5.5)$ & $0(0.0)$ & 13 & & & \\
\hline & Total, $\mathrm{n}(\%)$ & $237(100)$ & $64(100)$ & 301 & & & \\
\hline \multirow[t]{3}{*}{ Avoidability } & Non-avoidable, n (\%) & $74(56.5)$ & $35(59.3)$ & 109 & $X^{2}=0.13$ & 0.715 & - \\
\hline & Avoidable, $\mathrm{n}(\%)$ & $57(43.5)$ & $24(40.7)$ & 81 & & & \\
\hline & Total, n (\%) & $131(100)$ & $59(100)$ & 190 & & & \\
\hline \multicolumn{2}{|c|}{ Suicide news articles about people } & $\begin{array}{l}\text { Victoria } \\
(n=131)\end{array}$ & $\begin{array}{l}\text { Canary } \\
\text { Islands } \\
(\mathrm{n}=59)\end{array}$ & Total & $\begin{array}{l}\text { Statistical } \\
\text { Test }\end{array}$ & $P$-value & $\begin{array}{c}\text { Power } \\
\text { (\%) }\end{array}$ \\
\hline \multicolumn{2}{|c|}{ Level of adherence, mean (standard deviation) } & $11.8(3.84)$ & $5.69(3.52)$ & - & $t=10.4$ & $<0.001$ & 99.9 \\
\hline \multicolumn{2}{|c|}{ WTA level of adherence, mean (standard deviation) } & $11.38(2.59)$ & $9.54(2.97)$ & - & $t=4.32$ & $<0.001$ & 99.4 \\
\hline \multicolumn{2}{|c|}{ WTD level of adherence, mean (standard deviation) } & $0.42(3.25)$ & $-3.85(1.54)$ & - & $\mathrm{t}=12.28$ & $<0.001$ & 99.9 \\
\hline \multicolumn{2}{|c|}{ WTA1, n (\%) } & $119(90.8)$ & $59(100)$ & 178 & - & $0.019^{¥}$ & 86.2 \\
\hline \multicolumn{8}{|l|}{ Sensationalism } \\
\hline \multirow{2}{*}{\multicolumn{2}{|c|}{$\begin{array}{l}\text { WTA2, n (\%) } \\
\text { Headlines }\end{array}$}} & $62(47.3)$ & $14(23.7)$ & 76 & $x^{2}=9.44$ & 0.002 & 94.5 \\
\hline \multirow{2}{*}{\multicolumn{2}{|c|}{$\begin{array}{l}\text { Headlines } \\
\text { WTA3, n (\%) }\end{array}$}} & & & & & & \\
\hline & & $125(95.4)$ & $58(98.3)$ & 183 & - & $0.439^{*}$ & 11.8 \\
\hline \multicolumn{8}{|l|}{ Pictures or video } \\
\hline \multicolumn{2}{|l|}{ WTA4, n (\%) } & $125(95.4)$ & $57(96.6)$ & 182 & - & $0.999^{¥}$ & 5.2 \\
\hline \multicolumn{8}{|l|}{ Suicide notes } \\
\hline WTA5, n (\%) & & $128(97.7)$ & $33(55.9)$ & 161 & $X^{2}=54.9$ & $<0.001$ & 99.9 \\
\hline Visibility of news artic & & & & & & & \\
\hline WTA6, n (\%) & & $72(55.0)$ & $20(33.9)$ & 92 & $x^{2}=7.23$ & 0.007 & 86.0 \\
\hline Detailed account of $n$ & & & & & & & \\
\hline WTA7, n (\%) & & $126(96.2)$ & $40(67.8)$ & 166 & $X^{2}=29.7$ & $<0.001$ & 99.9 \\
\hline Detailed account of Ic & & & & & & & \\
\hline WTA8, n (\%) & & $130(99.2)$ & $59(100)$ & 189 & - & $0.999^{¥}$ & 0.84 \\
\hline Glorification & & & & & & & \\
\hline WTA9, n (\%) & & $131(100)$ & $59(100)$ & 190 & - & - & - \\
\hline Normalization & & & & & & & \\
\hline WTA10, n (\%) & & $127(96.9)$ & $54(91.5)$ & 181 & - & $0.139^{¥}$ & 48.3 \\
\hline Suicide as a solution & & & & & & & \\
\hline WTA11, n (\%) & & $108(82.4)$ & 57 (96.6) & 165 & $x^{2}=7.15$ & 0.008 & 90.8 \\
\hline Simplistic reasons & & & & & & & \\
\hline WTA12, n (\%) & & $131(100)$ & $58(98.3)$ & 189 & - & $0.311^{\#}$ & 52.9 \\
\hline Religious or cultural s & pes & & & & & & \\
\hline WTA13, n (\%) & & $121(92.4)$ & $54(91.5)$ & 175 & - & $0.999^{¥}$ & 6.4 \\
\hline Understandable respo & & & & & & & \\
\hline WTA14, n (\%) & & $117(89.3)$ & $56(94.9)$ & 173 & $X^{2}=1.57$ & 0.211 & 23.2 \\
\hline Blame & & & & & & & \\
\hline WTA15, n (\%) & & $106(80.9)$ & $46(78.0)$ & 152 & $X^{2}=0.22$ & 0.638 & 8.9 \\
\hline Repetition & & & & & & & \\
\hline WTD1, n (\%) & & $129(98.5)$ & $54(91.5)$ & 183 & - & $0.031^{¥}$ & 74.1 \\
\hline Completed suicide & & & & & & & \\
\hline WTD2, n (\%) & & $43(32.8)$ & $5(8.5)$ & 48 & $X^{2}=12.77$ & $<0.001$ & 99.9 \\
\hline Alternatives to suicide & & & & & & & \\
\hline WTD3, n (\%) & & $100(76.3)$ & $0(0.0)$ & 100 & $X^{2}=95.08$ & $<0.001$ & 99.9 \\
\hline Support resources & & & & & & & \\
\hline WTD4, n (\%) & & $55(42.0)$ & $13(22.0)$ & 68 & $X^{2}=7.04$ & 0.008 & 86.1 \\
\hline Risk factors and warn & & & & & & & \\
\hline WTD5, n (\%) & & $67(51.1)$ & $11(18.6)$ & 78 & $X^{2}=17.76$ & $<0.001$ & 99.9 \\
\hline Depression often assc & & & & & & & \\
\hline WTD6, n (\%) & & 68 (51.9) & $10(16.9)$ & 78 & $X^{2}=20.54$ & $<0.001$ & 99.9 \\
\hline Sympathy to the surv & & & & & & & \\
\hline $\begin{array}{l}\text { WTD7, } \mathrm{n}(\%) \\
\text { Educate the public }\end{array}$ & & $24(18.3)$ & $0(0.0)$ & 24 & $X^{2}=12.37$ & $<0.001$ & 99.9 \\
\hline
\end{tabular}

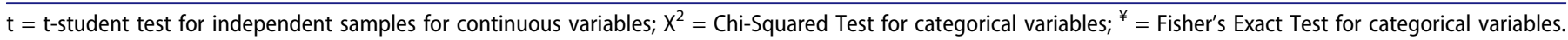

the assessment of the news articles was not blind to the group allocation. Some secondary analyses were underpowered and thus their interpretation must be made with caution. Finally, it cannot be assured that greater adherence in the postintervention period was due to the intervention. One strength of this study was that the inherent subjectivity in the 
evaluation was minimized by having two qualified evaluators and a systematic process until consensus was reached. In addition, a wide range of variables was assessed, including avoidability, which has not been evaluated so far, as well as subscales and each specific recommendation. Finally, the list of WHO recommendations assessed was taken from a recent publication, which was the result of a systematic process and was obtained from the three available WHO documents on this topic (Acosta Artiles et al., 2017).

\section{Conclusions}

Adherence to WHO recommendations on suicide news articles is low, especially to those related to protective effect. This finding suggests the need for training activities aimed at media professionals. Our findings support the effectiveness of simple interventions to improve adherence to $\mathrm{WHO}$ recommendations. Both simple interventions and constant interventions at multiple levels show effectiveness, although it is greater in the latter type. Since both contagion and protective effect are established in the literature, it is arguable that the effectiveness of these interventions will result in a preventive effect on suicide and suicidal behavior in the reference populations.

\section{Disclosure of potential conflicts of interest}

The authors have nothing to disclose regarding financial issues and report no conflicts of interest.

\section{ORCID}

Francisco J. Acosta (D) http://orcid.org/0000-0001-5835-2795

\section{References}

Acosta Artiles, F. J., Rodriguez Rodríguez-Caro, C. J., \& Cejas Méndez, M. R. (2017). Noticias sobre suicidio en los medios de comunicación. Recomendaciones de la OMS [Reporting on suicide. WHO recommendations for the media]. Revista Española de Salud Pública, 91, 24 de octubre e201710040.

Alexa. Alexa Internet, Inc. Retrieved from https://www.alexa.com/

Armstrong, G., Vijayakumar, L., Niederkrotenthaler, T., Jayaseelan, M., Kannan, R., Pirkis, J., \& Jorm, A. F. (2018). Assessing the quality of media reporting of suicide news in India against World Health Organization guidelines: A content analysis study of nine major newspapers in Tamil Nadu. Australian \& New Zealand Journal of Psychiatry, 52, 856-863. doi:10.1177/0004867418772343

Australian Bureau of Statistics (ABS). (2018). Quarterly population estimates (ERP), by state/territory, sex and age. Retrieved from http://stat. data.abs.gov.au/Index.aspx?DataSetCode=ERP_QUARTERLY

Australian Bureau of Statistics (ABS). (2019). Causes of death, Australia, 2017. Retrieved from http://www.abs.gov.au/ausstats/abs@.nsf/ Lookup/by\%20Subject/3303.0 2017 Main\%20Features Intentional\% 20self-harm,\%20key\%20characteristics 3

Australian Government under the National Suicide Prevention Program \& Everymind. The Australian government's Mindframe national media initiative. Retrieved from http://www.mindframe-media.info/

Blood, R. W., \& Pirkis, J. (2001). Suicide and the media: Part III. Theoretical issues. Crisis: The Journal of Crisis Intervention and Suicide Prevention, 22, 163-169. doi:10.1027//0227-5910.22.4.163

Bohanna, I., \& Wang, W. (2012). Media guidelines for the responsible reporting of suicide: A review of effectiveness. Crisis: The Journal of
Crisis Intervention and Suicide Prevention, 33, 190-198. doi:10.1027/ 0227-5910/a000137

Cheng, A. T., Hawton, K., Lee, C. T., \& Chen, T. H. (2007). The influence of media reporting of the suicide of a celebrity on suicide rates: A population-based study. International Journal of Epidemiology, 36, 1229-1234. doi:10.1093/ije/dym196

Chu, X., Zhang, X., Cheng, P., Schwebel, D., \& Hu, G. (2018). Assessing the use of media reporting recommendations by the World Health Organization in suicide news published in the most influential media sources in China, 2003-2015. International Journal of Environmental Research and Public Health, 15, 451. doi:10.3390/ijerph15030451

Etzersdorfer, E., \& Sonneck, G. (1998). Preventing suicide by influencing mass-media reporting. The Viennese experience 1980-1996. Archives of Suicide Research, 4, 67-74. doi:10.1080/13811119808258290

Frey, C., Michel, K., \& Valach, L. (1997). Suicide reporting in Swiss print media: Responsible or irresponsible? The European Journal of Public Health, 7, 15-19. doi:10.1093/eurpub/7.1.15

Fu, K. W., Chan, Y. Y., \& Yip, P. S. F. (2011). Newspaper reporting of suicides in Hong Kong, Taiwan and Guangzhou: Compliance with WHO media guidelines and epidemiological comparisons. Journal of Epidemiology \& Community Health, 65, 928-933. doi:10.1136/ jech.2009.105650

Fu, K. W., \& Yip, P. S. F. (2008). Changes in reporting of suicide news after the promotion of the WHO media recommendations. Suicide and Life-Threatening Behavior, 38, 631-636. doi:10.1521/ suli.2008.38.5.631

Gould, M. S., Midle, J. B., Insel, B., \& Kleinman, M. (2007). Suicide reporting content analysis: Abstract development and reliability. Crisis: The Journal of Crisis Intervention and Suicide Prevention, 28, 165-174. doi:10.1027/0227-5910.28.4.165

Herrera Ramírez, R., Ures Villar, M. B., \& Martínez Jambrina, J. J. (2015). El tratamiento del suicidio en la prensa española: ¿Efecto werther o efecto papageno? [The treatment of suicide in the Spanish press ¿werther Effect or Papageno Effect?]. Revista De La Asociación Española De Neuropsiquiatría, 35, 123-134. doi:10.4321/s021157352015000100009

Jamieson, P., Jamieson, K. H., \& Romer, D. (2003). The responsible reporting of suicide in print journalism. American Behavioral Scientist, 46, 1643-1660. doi:10.1177/0002764203254620

Michel, K., Wyss, K., Frey, C., \& Valach, L. (2000). An exercise in improving suicide reporting in print media. Crisis: The Journal of Crisis Intervention and Suicide Prevention, 21, 71-79. doi:10.1027// 0227-5910.21.2.71

Ministerio de Sanidad, Política Social e Igualdad (MSPSI). Grupo de trabajo de la Guía de Práctica Clínica de Prevención y Tratamiento de la Conducta Suicida. (2012). Guía de práctica clínica de prevención $y$ tratamiento de la conducta suicida [Clinical practice guidelines on prevention and treatment of suicidal behavior]. Madrid, Spain: Agencia de Evaluación de Tecnologías Sanitarias de Galicia, avalia-t. Consellería de Sanidad.

National Statistics Institute (NSI) [Instituto Nacional de Estadística] (2018a). Cifras oficiales de población resultantes de la revisión del padrón municipal a 1 de enero [Official population figures resulting from the revision of the municipal register on January 1]. Retrieved from https://www.ine.es/jaxiT3/Datos.htm?t=2915

National Statistics Institute (NSI) [Instituto Nacional de Estadística] (2018b). Encuesta sobre equipamiento y uso de tecnologías de información y comunicación en los hogares [Survey on equipment and use of information and communication technologies in homes]. Retrieved from https://www.ine.es/dyngs/INEbase/es/operacion.htm? $\mathrm{c}=$ Estadistica_C\&cid $=1254736176741 \&$ menu $=$ ultiDatos\&idp $=$ 1254735976608

National Statistics Institute (NSI) [Instituto Nacional de Estadística] (2019). Defunciones según la causa de muerte. Resultados por Comunidad Autónoma de residencia. Defunciones por causas (lista reducida) por sexo y grupos de edad. Año 2017 [Deaths by cause of death. Data by Autonomous Community of residence. Deaths by causes (reduced list) by sex and age groups. Year 2017]. Retrieved from http://www.ine.es/jaxiT3/Datos.htm?t=10803 
Niederkrotenthaler, T., \& Sonneck, G. (2007). Assessing the impact of media guidelines for reporting on suicides in Austria: Interrupted time series analysis. Australian and New Zealand Journal of Psychiatry, 41, 419-428. doi:10.1080/00048670701266680

Niederkrotenthaler, T., Till, B., Kapusta, N. D., Voracek, M., Dervic, K., \& Sonneck, G. (2009). Copycat effects after media reports on suicide: A population-based ecologic study. Social Science \& Medicine, 69, 1085-1090. doi:10.1016/j.socscimed.2009.07.041

Niederkrotenthaler, T., Voracek, M., Herberth, A., Till, B., Strauss, M., Etzersdorfer, E., ... Sonneck, G. (2010). Role of media reports in completed and prevented suicide: Werther v. Papageno effects. The British Journal of Psychiatry, 197, 234-243. doi:10.1192/bjp.bp.109.074633

Phillips, D. P., Lesyna, K., \& Paight, D. J. (1992). Suicide and the media. In R. W. Maris, A. L. Berman, J. T. Maltsberger, \& R. I. Yufit (Eds.), Assessment and prediction of suicide (pp. 499-519). New York, USA: The Guilford Press.

Pirkis, J., Blood, R. W., Beautrais, A., Burgess, P., \& Skehan, J. (2006). Media guidelines on the reporting of suicide. Crisis: The Journal of Crisis Intervention and Suicide Prevention, 27, 82-87. doi:10.1027/02275910.27.2.82

Pirkis, J., Dare, A., Blood, R. W., Rankin, B., Williamson, M., Burgess, P., \& Jolley, D. (2009). Changes in media reporting of suicide in Australia between 2000/01 and 2006/07. Crisis: The Journal of Crisis Intervention and Suicide Prevention, 30, 25-33. doi:10.1027/0227-5910.30.1.25

Ramadas, S., \& Kuttichira, P. (2011). The development of a guideline and its impact on the media reporting of suicide. Indian Journal of Psychiatry, 53, 224-228. doi:10.4103/0019-5545.86812
Scherr, S., Markiewitz, A., \& Arendt, F. (2019). Effectiveness of a workshop intervention on responsible reporting on suicide among Swiss media professionals. Crisis, 1-5. doi:10.1027/0227-5910/a000584

Sisask, M., \& Värnik, A. (2012). Media roles in suicide prevention: A systematic review. International Journal of Environmental Research and Public Health, 9, 123-138. doi:10.3390/ijerph9010123

Skehan, J., Greenhalgh, S., Hazell, T., \& Pirkis, J. (2006). Reach, awareness and uptake of media guidelines for reporting suicide and mental illness: An Australian perspective. International Journal of Mental Health Promotion, 8, 29-35. doi:10.1080/ 14623730.2006.9721749

Stack, S. (2003). Media coverage as a risk factor in suicide. Journal of Epidemiology and Community Health, 57, 238-240. doi:10.1136/ jech.57.4.238

Stack, S. (2005). Suicide in the media: A quantitative review of studies based on nonfictional stories. Suicide and Life-Threatening Behavior, 35, 121-133. doi:10.1521/suli.35.2.121.62877

Tatum, P. T., Canetto, S. S., \& Slater, M. D. (2010). Suicide coverage in US newspapers following the publication of the media guidelines. Suicide and Life-Threatening Behavior, 40, 524-534. doi:10.1521/ suli.2010.40.5.524

World Health Organization. (2000). Preventing suicide: A resource for media professionals. Geneva, Switzerland: Author.

World Health Organization. (2008). Preventing suicide: A resource for media professionals. Geneva, Switzerland: Author.

World Health Organization. (2017). Preventing suicide: A resource for media professionals, update 2017. Geneva, Switzerland: Author. 


\section{Appendix}

List of WHO recommendations disseminated to media professionals in the Canary Islands*

\section{WHAT TO AVOID}

1. Do not sensationalize suicide.

2. Avoid headlines containing the word "suicide" or specifying the method or location.

3. Be cautious with the use of pictures or video footage. Avoid pictures or video of the deceased, of the method used, of the scene, of shocking contents (i.e. person on a ledge or similar, or elements used), and of links to social networks that contain them.

4. Do not publish suicide notes in any of their forms (paper, final text messages, social media posts or emails)

5. Do not place suicide news articles prominently. Newspaper stories about suicide should be located on the inside pages.

6. Avoid providing detailed information or an explicit description of the method used of a completed or attempted suicide.

7. Avoid providing detailed information about the location of a completed or attempted suicide.

8. Do not glorify the person who has committed suicide.

9. Do not use language that normalizes suicide.

10. Do not depict suicide as a solution to problems or as a means of coping with personal problems.

11. Do not provide simplistic reasons for why the suicide occurred.

12. Do not use religious or cultural stereotypes.

13. Avoid reporting suicidal behavior as an understandable response to social or cultural changes or degradation.

14. Do not apportion blame.

15. Do not unduly repeat suicide news articles.

\section{WHAT TO DO}

1. Refer to suicide as a "completed suicide", not as a "successful suicide".

2. Highlight alternatives to suicide, either through general information or through stories of people illustrating how to cope with adverse circumstances or suicidal thoughts, and how to get help.

3. Provide information about support resources and crisis helplines.

4. Provide information about risk factors and warning signs.

5. Convey the message that depression is often associated with suicidal behavior and that depression is a treatable condition.

6. Offer a message of sympathy to the survivors in their hour of grief and provide telephone numbers of support groups for survivors, if available.

7. Educate the public about the facts of suicide and suicide prevention, without spreading myths.

*English version of the Spanish compendium of WHO recommendations, which can be found in Acosta Artiles et al. (2017). 